\title{
Review
}

\section{Geographical patterns of threat among pigeons and doves (Columbidae)}

Jonathan S. Walker

\begin{abstract}
Columbidae (pigeons and doves) is one of the most threatened bird families in the world. I analysed data on the BirdLife International Species Information Database to examine the distribution and causes of threat among columbids. Of 304 species extant in the wild, $59(19 \%)$ are threatened with extinction, $48(83 \%)$ of which have restricted ranges. All but two threatened columbid species (97\%) inhabit tropical forests, and of these, 45 are island species $(78 \%$ of all threatened columbid species). The taxonomic distribution of columbids follows three coherent areas: the Americas; Europe, Africa, the Middle East and Central Asia; Asia, Australasia and Oceania. Asia, Australasia and Oceania support nearly two-thirds of all extant species and three-quarters of threatened species (44), most of which $(84 \%)$ are restricted range insular species. Three countries within this area are the most important
\end{abstract}

for the conservation of columbid diversity: Indonesia, the Philippines and French Polynesia. Together these three countries support $40 \%$ of extant species and half of all threatened species. The greatest causes of threat to columbids are (1) habitat loss and fragmentation due to agriculture and extraction, (2) hunting for food, and (3) alien predator species. Habitat loss and fragmentation are universal threats to columbids. Hunting, however, is a significantly greater threat to species in Asia, Australasia and Oceania than to species in the other two areas and urgently needs to be addressed. I discuss the conservation implications of these findings and make research recommendations to aid and encourage the conservation of threatened columbids and their habitats.

Keywords Columbidae, doves, French Polynesia, habitat loss, hunting, Indonesia, Philippines, pigeons.

\section{Introduction}

Columbidae (pigeons and doves) is a globally represented family of birds yet it has received relatively little conservation attention. Pigeons and doves are represented on every continent except Antarctica and in habitats as diverse as tropical rainforests, deserts, mountains and cities (Goodwin, 1983; Baptista et al., 1997; Gibbs et al., 2001). Despite the evolutionary success of the Columbidae, the family contains a significantly greater proportion of threatened species than expected by chance (Bennett \& Owens, 1997), possibly because it is one of a small number of bird families that are prone to human persecution, introduced predators and habitat loss (Owens \& Bennett, 2000).

Columbid diversity is highest in the forests of the tropics where the many frugivorous columbids, through their role as seed dispersers, are ecologically important in the maintenance of tropical forest diversity (Stiles, 1985; Corlett, 1998; McConkey et al., 2004) and in some

Jonathan S. Walker Economic Studies, University of Manchester, Manchester, M13 9PL, UK. E-mail jon@columbidae.org.uk

Received 28 October 2005. Revision requested 19 May 2006. Accepted 6 October 2006. cases are the only vector by which seeds of certain tree species are dispersed (Meehan et al., 2005). Columbids are also fundamental agents in the regeneration of nonwooded areas and are among the most important agents in the colonization and building of wooded habitats on islands (Whittaker \& Jones, 1994; Whittaker \& Turner, 1994; Thornton et al., 1996). As a consequence, local declines in frugivorous columbid populations may have long-term detrimental effects for regeneration of tropical forest ecosystems (Chapman \& Chapman, 1995; Wright \& Duber, 2001). In extreme cases, the loss of columbid species may result in some plants having no means of seed dispersal (Hamann \& Curio, 1999; McConkey \& Drake, 2002).

In this paper I review the distribution of and threats to Columbidae and identify priority areas for the conservation of pigeon and doves and the forests they maintain.

\section{Methods}

I used the data available on the BirdLife International (2007) Bird Information Database, and latest updates supplied by BirdLife International, to examine threats to the Columbidae, and I follow the current columbid taxonomy adopted by BirdLife International. These data provide the information for species accounts used for 
birds on the IUCN Red List (IUCN, 2006). From the information held on the Bird Information Database I extracted conservation status, distribution (region and country), habitats, threats and data quality. I identified restricted-range species from a data set supplied to me by BirdLife International. Information on the origins of islands inhabited by Columbidae (continental or oceanic) was taken from Stattersfield et al. (1998), and the classification of species as terrestrial or arboreal and data about bird sizes were obtained from Gibbs et al. (2001). I collated and analysed these data to examine patterns in extinction risk of Columbidae.

\section{Results}

\section{Conservation status}

BirdLife International currently recognizes 317 species of columbid, 12 of which are already extinct and one species, the Socorro dove Zenaida graysoni, which is extinct in the wild. Of the 304 species extant in the wild, $19.4 \%$ (59) are categorized as Threatened and a further $12.5 \%$ (38) as Near Threatened. Overall, nearly one third of extant columbids face some degree of extinction threat. Of the threatened species, $10(16.9 \%)$ are categorized as Critically Endangered, 15 (25.4\%) as Endangered and 34 (57.6\%) as Vulnerable. Only one species is currently showing signs of recovery, the pink pigeon Streptopelia mayeri, as a result of intense conservation effort. Fifty-two species (88.1\%) have populations that are still in decline, although six species (10.3\%) have global populations that are stable. The availability and quality of the data available for most threatened species are described as poor (for 24 species) or medium (27 species); good data are available for only eight species.

\section{Geographical distribution}

There are three coherent areas of columbid taxonomic distribution: the Americas; Europe, Africa, the Middle East and Central Asia; and Asia, Australasia and Oceania (Fig. 1, Appendix). There are 12 genera and 72 species in the Americas. Nine of these genera (containing 63 species) are endemic to the area (Appendix). The columbids of Europe, Africa, the Middle East and Central Asia are similar as they comprise entirely, or are dominated by, species of Columba and Streptopelia. There are 55 species in this area but with the exception of Africa (47 species), the individual regions have low columbid diversity (Table 1, Appendix). In contrast, there are 196 species of columbid in Asia, Australasia and Oceania, representing $64.5 \%$ of the columbid species extant in the wild. There are strong taxonomic affinities within the area: Asia and Australia have 15 genera in common, and Oceania shares four of its five columbid genera with
Asia and Australia. These genera are all endemic to these three regions and account for over a third (104) of all extant columbid species (Table 1, Appendix).

Asia, Australasia and Oceania support 75.9\% (44) of all threatened species (Fig. 2, Table 1). This is $22.4 \%$ of the area's columbid species, a larger percentage than in the Americas $(15.7 \%, \mathrm{n}=11)$ or Europe, Africa, the Middle East and Central Asia $(9.8 \%, n=5)$. However, this difference is not significant when species representation within each area is controlled $(45 / 196,11 / 72$ and 5/55, respectively; $G=5.242, \mathrm{df}=2, \mathrm{P}=0.091$ ).

Asia, Australasia and Oceania is the area of greatest importance in the conservation of columbid diversity. Within this area the region with the highest columbid diversity is Asia, containing $44.1 \%$ (134 species) of all extant species and $44.8 \%$ of all threatened species. Australia is the region with the second richest columbid diversity, containing $24.7 \%$ of species (75) and $13.6 \%$ of threatened species. Oceania supports just $9.5 \%$ of extant species (29) but with 12 (41.4\%) of these species listed as threatened, a fifth of all threatened species occur there.

In terms of the numbers of threatened species, certain countries are particularly important for columbid conservation. Of the eight countries with three or more threatened species, all are either in Asia, Australasia or Oceania (Table 2). Indonesia has 93 species, more than any other country and nearly a third of the world's species. All Indonesian species are still extant, although $12.9 \%$ (12) are currently threatened. The Philippines has 11 threatened species, which is nearly one-third of its 34 columbid species (all extant). In French Polynesia, two-thirds (6/9) of extant species currently face extinction, the greatest proportion of any country.

\section{Range sizes}

There are more restricted range species in Asia, Australasia and Oceania $(98 / 196,50.0 \%$ of species) than in the Americas (18/72, 25.0\%) or Europe, Africa, the Middle East and Central Asia $\left(14 / 55,25.5 \% ; G_{\text {adj }}=20.32, \mathrm{df}=2\right.$, $\mathrm{P}=0.000)$. Forty-nine $(83.1 \%)$ of threatened species have restricted ranges and all but six of these are insular species (one species, the large green pigeon Treron capellei, is both a continental and insular species, and for the purposes of this study is treated as continental; Table 1). Restricted range insular species have a significantly greater representation among threatened species than expected (21.2 species) from the global numbers of extant restricted-range insular species $\left(109 / 304 ; G_{\text {adj }}=\right.$ 33.31, $\mathrm{df}=1, \mathrm{P}=0.000)$. Asia, Australasia and Oceania supports 37 of these threatened restricted-range insular species, $86.6 \%$ of the regions' threatened species and significantly more than expected (22 species, calculated from the proportion of restricted range insular species in 


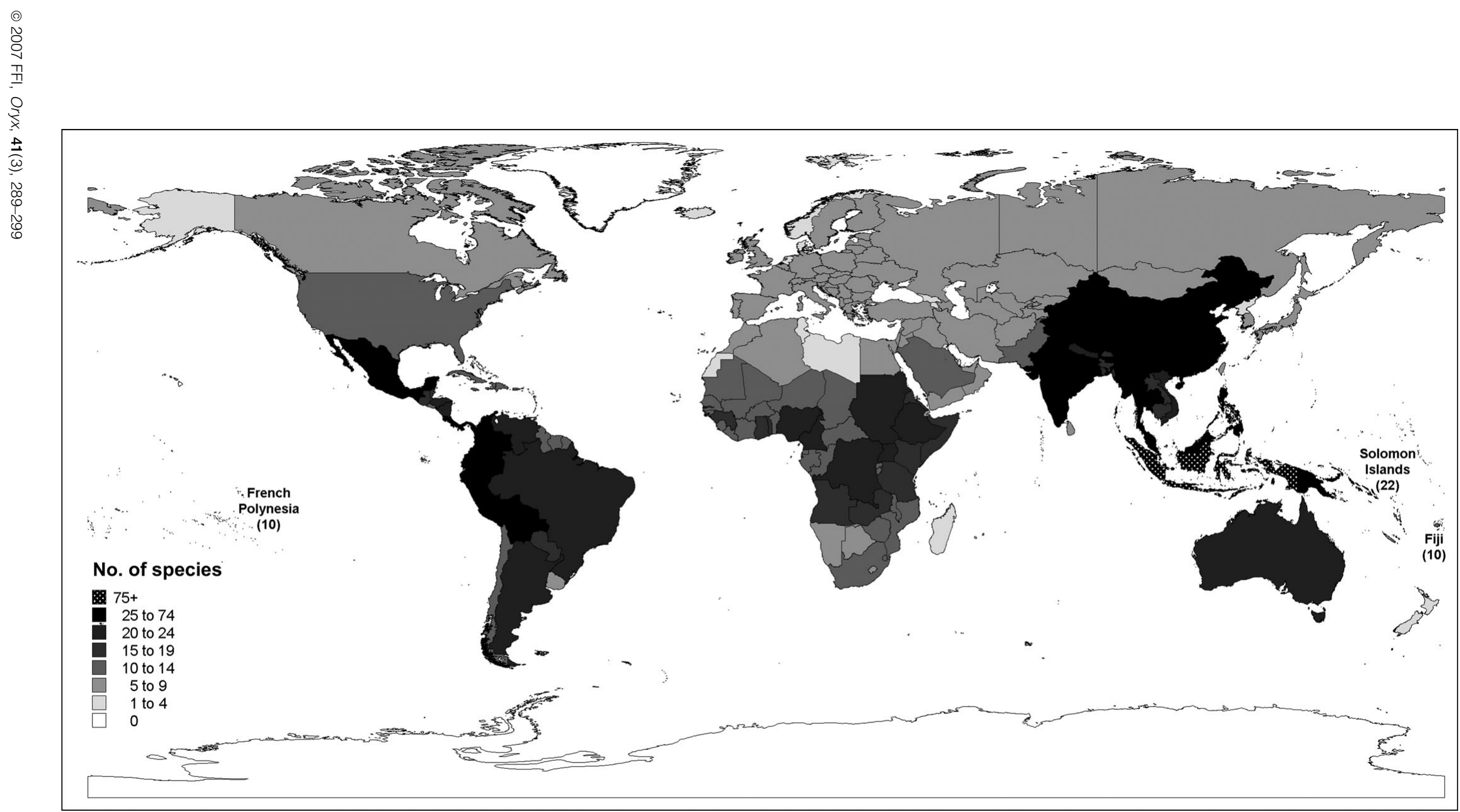

Fig. 1 Number of columbid species in each country, including extinct species, with the number of species presented directly for selected islands. Species from remote territories are not attributed to mainland totals; for example, species on the Canary Islands are not included in the count for mainland Spain. 


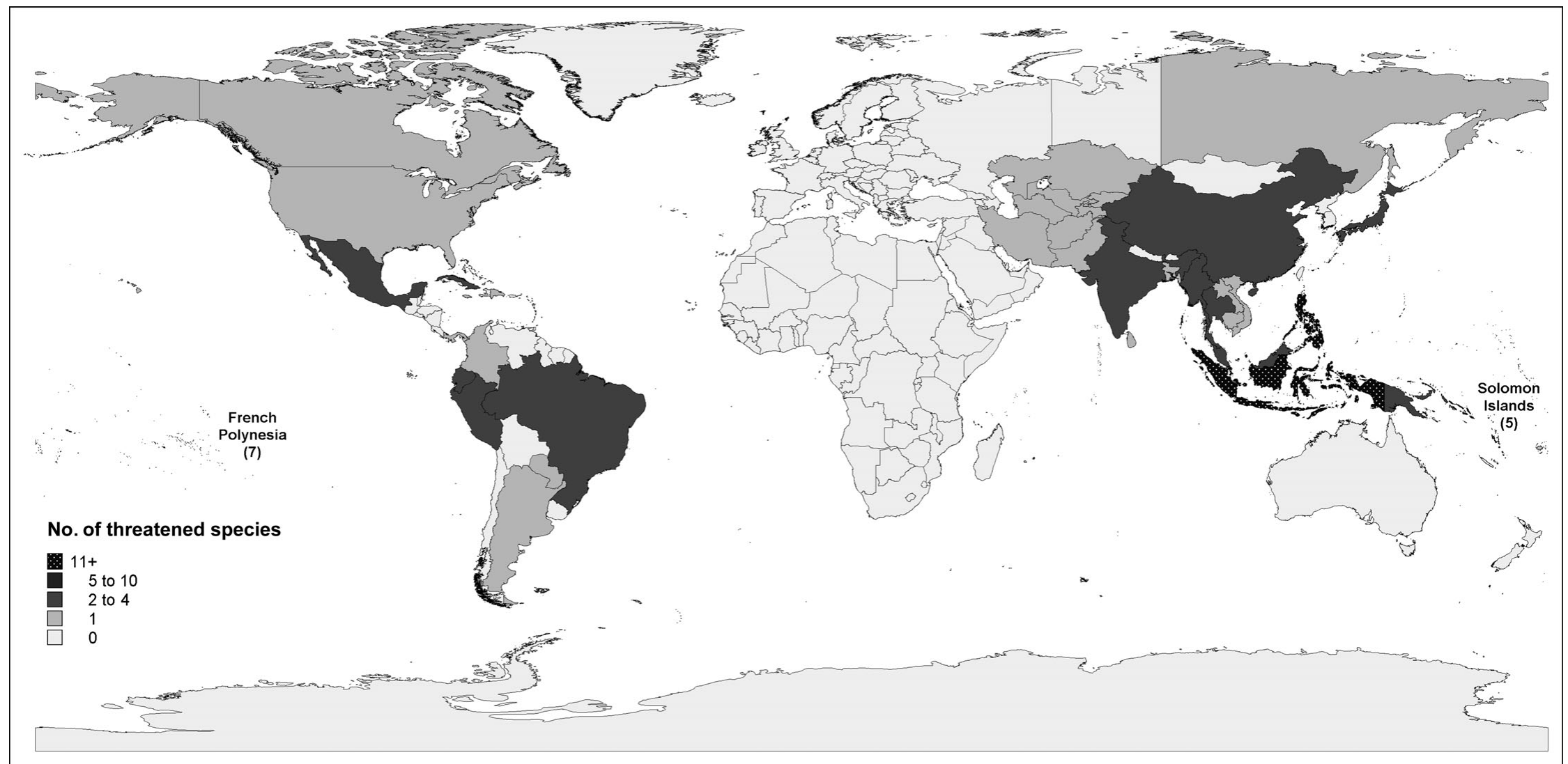

Fig. 2 Number of threatened (i.e. Critically Endangered, Endangered and Vulnerable) columbid species in each country, with the number of species presented directly for islands that have $\geq 5$ threatened species. Threatened species on remote territories are not attributed to mainland totals; for example, threatened species on the Canary Islands are not included in the threatened species count for mainland Spain. 
Table 1 Numbers of Extinct, Threatened and Near Threatened columbid species in the Americas, Europe, Africa, the Middle East and Central Asia, and Asia, Australia and Oceania, and in regions within these three areas.

\begin{tabular}{|c|c|c|c|c|c|c|c|c|c|c|c|c|c|c|}
\hline \multirow[b]{2}{*}{ Area \& region } & \multicolumn{10}{|c|}{ All species ${ }^{1}$} & \multicolumn{4}{|c|}{ Threatened species (CR, EN \& VU) } \\
\hline & $\begin{array}{l}\text { No. }(\% \\
\text { of total) }\end{array}$ & $\begin{array}{l}\text { No. } \\
R^{2}\end{array}$ & EX & EW & $\mathrm{CR}$ & EN & VU & NT & LC & DD & $\begin{array}{l}\text { No. (\% } \\
\text { of total) }\end{array}$ & $\% R^{2}$ & Continental & Insular \\
\hline \multicolumn{15}{|l|}{ Americas } \\
\hline Antarctica $^{3}$ & $1(0.3)$ & 0 & & & & & & & 1 & & 0 & 0.0 & & \\
\hline N America & $17(5.4)$ & 0 & 1 & & & & & 1 & 15 & & 0 & 0.0 & & \\
\hline C America & 35 (11.1) & 6 & & 1 & & 1 & 1 & 2 & 30 & & $2(5.8)$ & 100.0 & 2 & \\
\hline Caribbean & $30(9.5)$ & 4 & & & 1 & 1 & 2 & 3 & 23 & & $4(12.9)$ & 50.0 & & 4 \\
\hline Andes America & $47(14.9)$ & 7 & & & & 1 & 2 & 2 & 42 & & $3(6.4)$ & 100.0 & 3 & \\
\hline S America & $33(10.1)$ & 9 & & & 2 & & & & 31 & & $2(6.1)$ & 0.0 & 2 & \\
\hline Total & $72(22.7)$ & 18 & 1 & 1 & 3 & 3 & 5 & 4 & 55 & & $11(15.3)$ & 63.6 & 7 & 4 \\
\hline \multicolumn{15}{|c|}{ Europe, Africa, the Middle East and Central Asia } \\
\hline Europe & $10(3.2)$ & 3 & & & & 1 & & 2 & 7 & & $1(10.0)$ & 100.0 & & 1 \\
\hline Middle East & $14(4.4)$ & 0 & & & & & 1 & & 13 & & $1(7.1)$ & 0.0 & & 1 \\
\hline Africa & $47(14.9)$ & 11 & 4 & & & 1 & 2 & 3 & 36 & $1^{4}$ & $3(6.4)$ & 100.0 & & 3 \\
\hline C Asia & $11(3.5)$ & 0 & & & & & 1 & & 10 & & $1(9.1)$ & 0.0 & 1 & \\
\hline Total & $55(17.4)$ & 14 & 4 & & & 2 & 3 & 5 & 40 & 1 & $5(9.1)$ & 80.0 & 1 & 4 \\
\hline \multicolumn{15}{|c|}{ Asia, Australia and Oceania } \\
\hline Asia & $136(43.0)$ & 50 & 2 & & 5 & 4 & 17 & 16 & 92 & & $26(19.4)$ & 76.9 & $4^{5}$ & 22 \\
\hline Australasia & $78(24.7)$ & 24 & 4 & & & 2 & 6 & 9 & 57 & & $8(10.8)$ & 75.0 & & 8 \\
\hline Oceania & $30(9.5)$ & 25 & 1 & & 2 & 4 & 6 & 6 & 11 & & $12(41.4)$ & 100.0 & & 12 \\
\hline Total & $203(64.0)$ & 98 & 7 & & 8 & 10 & 26 & 29 & 123 & & $44(74.6)$ & 86.4 & 4 & 20 \\
\hline Global $^{6}$ & 317 & 130 & 12 & 1 & 10 & 15 & 34 & 38 & 206 & 1 & 59 (19.4) & 86.4 & 11 & 48 \\
\hline
\end{tabular}

${ }^{1}$ EX, Extinct; EW, Extinct in the wild; CR, Critically Endangered; EN, Endangered; VU, Vulnerable; NT, Near Threatened, LC, Least Concern; DD, Data Deficient

${ }^{2}$ With restricted range

${ }^{3}$ Eared dove Zenaida auriculata occurs on South Georgia and the South Sandwich Islands

${ }^{4}$ Insufficient data are available to assess accurately the threat status of the Somali pigeon Columba oliviae.

${ }^{5}$ Large green pigeon Treron capellei is both a continental and insular species, and treated here as continental.

${ }^{6} 11$ species occur in more than one area: 9 occur in Asia, Australasia and Oceania and Europe, Africa, the Middle East and Central Asia; and 2 occur in all three areas.

these regions; $\left.G_{\text {adj }}=24.20, \mathrm{df}=1, \mathrm{P}=0.000\right)$. Seven of the 11 threatened species with continental distributions are from South and Central America and represent all the threatened species within these two regions.

\section{Altitudinal range}

Threatened columbids have narrower altitudinal ranges (mean 1,094 \pm SD $627 \mathrm{~m}, \mathrm{n}=48$ ) than columbids of Least Concern (mean 1,652 \pm SD $831 \mathrm{~m}, \mathrm{n}=180$; $t=1.971, \mathrm{df}=175.4, \mathrm{P}=0.050)$, because despite their having significantly lower minimum altitudinal extents (mean $112 \pm$ SD $274 \mathrm{~m}, \mathrm{n}=57$ and mean $213 \pm$ SD $510 \mathrm{~m}$, $\mathrm{n}=193$ respectively; $t=1.971, \mathrm{df}=175.4, \mathrm{P}=0.000$ ), the maximum elevations of their ranges are also significantly lower (mean 1,232 \pm SD $688 \mathrm{~m}, \mathrm{n}=47$ ) than those of columbids of Least Concern (mean 1,881 \pm SD $1,022 \mathrm{~m}, \mathrm{n}=180 ; t=5.158, \mathrm{df}=105.3, \mathrm{P}=0.000)$.

\section{Habitats}

All threatened columbids are subtropical/tropical species with the sole exception of the pale-backed pigeon
Columba eversmanni, which is a winter visitor to the subtropics/tropics from its breeding grounds in arable lands further north. Of the subtropical/tropical columbids, all inhabit forest except for the blue-eyed ground dove Columbina cyanopis, which is a grassland species. Forests are classified as either a critical or major habitat for 56 threatened species $(94.9 \%)$.

\section{Status of terrestrial versus arboreal columbids}

Terrestrial columbids account for $38.2 \%$ (116/304) of extant species and are better represented in the Americas (51, $75.0 \%$ of species) than in Europe, Africa, the Middle East and Central Asia (17, 42.5\% of species) and Asia, Australasia and Oceania (43, 23.2\% of species; $G=$ $57.17, \mathrm{df}=2, \mathrm{P}=0.000)$. Terrestrial columbids account for $40.7 \%$ (24) of threatened species and are neither over nor under represented in relation to their global species representation $\left(G_{\text {adj }}=2.27, \mathrm{df}=1, \mathrm{P}=0.165\right)$. There are more threatened terrestrial species in Asia, Australasia and Oceania (14) than in either the Americas (9) or Europe, Africa, the Middle East and Central Asia (1). 
Table 2 The number of Extinct, threatened (Critically Endangered, Endangered, Vulnerable), Near Threatened and Least Concern species of Columbidae in countries with three or more threatened species (with \% of total species in each country in parentheses).

\begin{tabular}{|c|c|c|c|c|c|c|c|c|}
\hline Category $^{1}$ & $\begin{array}{l}\text { Indonesia } \\
\text { (Asia) }\end{array}$ & $\begin{array}{l}\text { Philippines } \\
\text { (Asia) }\end{array}$ & $\begin{array}{l}\text { French Polynesia } \\
\text { (Oceania) }\end{array}$ & $\begin{array}{l}\text { Papua New } \\
\text { Guinea (Aust.) }\end{array}$ & $\begin{array}{l}\text { Malaysia } \\
\text { (Asia) }\end{array}$ & $\begin{array}{l}\text { Solomon Islands } \\
\text { (Aust.) }\end{array}$ & $\begin{array}{l}\text { Timor-Leste } \\
\text { (Asia) }\end{array}$ & $\begin{array}{l}\text { India } \\
\text { (Asia) }\end{array}$ \\
\hline EX & & & $1(10.0)$ & & & $2(9.1)$ & & \\
\hline CR & $1(1.1)$ & $4(14.7)$ & $2(20.0)$ & & $1(4.0)$ & & & \\
\hline EN & $3(3.2)$ & $1(2.9)$ & $2(20.0)$ & $1(2.1)$ & & $2(9.1)$ & $3(50.0)$ & \\
\hline VU & $8(8.6)$ & $6(14.7)$ & $2(20.0)$ & $3(6.4)$ & $3(12.0)$ & $1(4.5)$ & & $3(10.7)$ \\
\hline NT & $9(9.7)$ & $5(14.7)$ & $1(10.0)$ & $3(6.4)$ & $3(12.0)$ & $3(13.6)$ & $2(33.3)$ & $3(10.7)$ \\
\hline $\mathrm{LC}$ & $72(77.4)$ & $18(52.9)$ & $2(10.0)$ & $40(85.1)$ & $19(76.0)$ & $14(63.6)$ & $1(16.6)$ & $22(78.6)$ \\
\hline Total & 93 & 34 & 10 & 47 & 25 & 22 & 6 & 28 \\
\hline Total extant ${ }^{2}$ & 93 & 34 & 9 & 47 & 25 & 20 & 6 & 28 \\
\hline Threatened $^{3}$ & $12(12.9)$ & $11(32.4)$ & $6(66.7)$ & $4(8.5)$ & $4(16.0)$ & 3 (13.6) & $3(50.0)$ & $3(10.7)$ \\
\hline
\end{tabular}

${ }^{1}$ See footnote to Table 1

${ }^{2}$ Extant in the wild

${ }^{3}$ Expressed as number of species (\% of total number of extant species in each country)

However, neither terrestrial (nor arboreal) species are over or under represented among threatened species in the Americas (obs. $=9$, exp. $=8.25 ; G_{\text {adj }}=0.280, \mathrm{df}=1$, $\mathrm{P}=0.597)$, Europe, Africa, the Middle East and Central Asia (obs. $=1$, exp. $=2.55 ; G_{\text {adj }}=1.697, \mathrm{df}=1, \mathrm{P}=0.193$ ) or Asia, Australasia and Oceania (obs. $=14$, exp. $=9.98$, $\left.G_{\text {adj }}=1.93, \mathrm{df}=1, \mathrm{P}=0.165\right)$.

\section{Threats}

The threats cited as reasons for categorizing columbids as at risk from extinction are presented in Table 3. There are three major threats to columbids: habitat loss, hunting and invasive alien predators. Habitat loss/ degradation is listed as a pressure to all threatened species except the Marquesan ground-dove Gallicolumba rubescens, which is at risk solely as a result of alien predators. The type or cause of habitat loss/degradation is identified for 49 species. Agriculture affects most of these $(45,91.8 \%)$ followed by either wood extraction or mining $(38,77.6 \%)$. Over half of the threatened species are affected by both agriculture and extraction (32, $54.2 \%)$ whereas just eight species $(13.6 \%)$ are threatened by a single type of pressure on their habitat. The level of forest fragmentation within species' ranges has been qualified for 56 threatened species. Of these, only five species $(8.9 \%)$ have experienced no forest fragmentation, 36 species $(64.3 \%)$ have experienced some and 15 species $(26.8 \%)$ have experienced severe fragmentation.

Hunting affects just over three-quarters of threatened species (45). Most (41) are hunted as a source of food, with this pressure more prevalent among species in Asia, Australasia and Oceania than in the Americas or Europe, Africa, the Middle East and Central Asia $\left(G_{\text {adj }}=9.40, \mathrm{df}=2, \mathrm{P}=0.009\right)$. This may reflect their relative attractiveness as a source of bushmeat, for example, because columbid species in Americas are c. 17\% smaller (mean wing length $=149 \pm$ SD $40.6 \mathrm{~mm}$, $\mathrm{n}=67$ ) than species in Europe, Africa, the Middle East and Central Asia (mean $182 \pm$ SD $45.8 \mathrm{~mm}, \mathrm{n}=40$ ) and

Table 3 The threats implicated in the extinction risks of Columbidae. Values are number of species (\% of species within each threat area or class).

\begin{tabular}{llllll}
\hline & & $\begin{array}{l}\text { Europe, Africa, the } \\
\text { Aiddle East \& Central } \\
\text { Threat }\end{array}$ & $\begin{array}{l}\text { Asia, Australasia } \\
\text { \& Oceania } \\
(\mathrm{n}=11)\end{array}$ & $\begin{array}{l}\text { Asia }(\mathrm{n}=5) \\
\text { All threatened spp. }\end{array}$ & $\begin{array}{l}\text { Near Threatened } \\
(\mathrm{n}=38)\end{array}$ \\
\hline Habitat loss & $11(100)$ & $5(100)$ & $43(97.7)$ & $58(98.3)$ & $35(92.1)$ \\
Hunting & $5(45.5)$ & $3(60.0)$ & $38(86.4)$ & $45(76.3)$ & $19(50.0)$ \\
Invasive alien species & $2(18.2)$ & $2(40.0)$ & $15(34.1)$ & $18(30.5)$ & $8(21.1)$ \\
Natural disasters* & $1(9.1)$ & $0(0.0)$ & $4(9.1)$ & $6(10.2)$ & $2(5.3)$ \\
Intrinsic factors & $0(0.0)$ & $1(20.0)$ & $1(2.3)$ & $1(1.7)$ & $1(2.6)$ \\
Pollution & $0(0.0)$ & $0(0.0)$ & & & $1(2.6)$ \\
Accidental mortality & & & 5 & 6 & $1(2.6)$ \\
Persecution & & 4 & & & 7 \\
No threat categories & 4 & & & & \\
\hline
\end{tabular}

*Storms/flooding 
Asia, Australasia and Oceania (mean $179 \pm$ SD $53.8 \mathrm{~mm}$, $\left.\mathrm{n}=186 ; F_{2,290}=9.751, \mathrm{P}=0.000\right)$. No more terrestrial than arboreal species are threatened as a result of being hunted for food than expected $\left(G_{\text {adj }}=1.407\right.$, $\mathrm{df}=1$, $\mathrm{P}=0.236)$. Nine species $(15.5 \%)$, all Asian, are threatened by the cage bird trade, seven are hunted for sport, and the three crowned pigeons Goura spp. are hunted for cultural activities (Table 3).

Invasive alien predators are a threat to 19 species $(32.8 \%)$. Four of these species also suffer the additional threat of introduced pathogens/parasites and competitors. Alien species are only listed as a threat to insular species, predominantly oceanic island species (18 out of 19 species). Terrestrial and arboreal species are equally threatened by invasive alien predators $\left(G_{\text {adj }}=0.951\right.$, $\mathrm{df}=1, \mathrm{P}=0.329$ ).

\section{Future threatened columbids}

Of the 38 Near Threatened columbid species all but one inhabits subtropical/tropical forest. Habitat loss is the reason for the categorization of $92.1 \%$ of these species, hunting for $50.0 \%$ of species, and both are reasons for the categorization of $47.0 \%$ of Near Threatened species. Eight species are Near Threatened partially or solely because of introduced species, seven of which are island species (Table 3). Asia, Australasia and Oceania are home to over three-quarters (29) of Near Threatened species. Two-thirds (23) of these are restricted-range insular species; significantly more than expected for the area (exp. $=13.9$ species, calculated from the proportion of species in these regions that are restrictedrange island species, 94/196; $G_{\text {adj }}=11.885, \mathrm{df}=1$, $\mathrm{P}=0.0005)$. One-third (12) of these species only occur in Asia, which supports 16 (42.1\%) of all Near Threatened species. Indonesia supports nine of these species and the Philippines five species. Combined, these two countries support over a third (13) of all Near Threatened species.

\section{Discussion}

\section{Patterns of threat}

Fifty-nine species of Columbidae, 19\% of all species, are currently threatened with extinction. These are virtually all confined to the tropics, are dependent on forests, and predominantly inhabit islands and have restricted ranges. Over three-quarters of all threatened columbid species live in the tropical forests of Asia, Australasia and Oceania, where $91 \%$ inhabit islands, $86 \%$ have restricted ranges, and $64 \%$ are insular species with restricted ranges. Small geographic ranges and endemism have previously been identified to be significantly associated with extinction risk among columbid species (Hughes, 2004), and reliance on rare food resources has been identified as a correlate of their local rarity (Walker, 2006). Countries or territories within Asia, Australasia, and Oceania are the most important for the conservation of columbid diversity. The islands of the Indonesian and Philippine archipelagos and the islands of French Polynesia are of exceptional importance as together they support $40 \%$ of all extant species of columbid and half of all threatened species.

\section{Threats}

The threats affecting most species of threatened columbids are habitat loss and degradation, hunting, and invasive alien species.

Habitat loss Habitat loss is the greatest threat facing columbid diversity. It is listed as a threat to all but one threatened species. Halting, and for some species reversing, forest loss, fragmentation and degradation is essential to the global conservation of threatened pigeons and doves. The Americas and Africa have greater rates of deforestation than Asia, Australasia and Oceania (FAO, 2005) and this is currently the greatest cause of threat in these areas. Forest clearance has been high within Asian countries in the past. For example, Indonesia, which has the greatest columbid diversity and the most threatened columbids, has lost $40 \%$ of its forests since 1950 (FWI/GFW, 2002). That so many threatened species occur on islands within Asia, Australasia and Oceania probably reflects the fact that even the lower contemporaneous rates of clearance on small tropical islands significantly reduces overall forest cover.

It is not just the extent, but also the quality of remaining forest that affects columbids. Many species have been identified as being affected by fragmentation because they display minimum thresholds in the size of the forest they inhabit or visit (Warburton, 1997; Jati, 1998; Price et al., 1999). Different species are also affected by different habitat qualities (Marsden, 1998; Kavanagh \& Stanton, 2005; Peh et al., 2005). Threatened columbid species, however, tend to favour primary forest (Jones et al., 1995; Peh et al., 2005) and are therefore negatively affected by forest degradation.

Hunting Hunting is a greater threat to species at risk of extinction in Asia, Australasia and Oceania than in the rest of the world. This may be because on the islands that make up these regions agricultural protein production may not meet demand or bushmeat may be a preferred source of protein. Columbids may be targeted as there may be fewer or less attractive, sources of bushmeat than in the rest of the world (columbids are larger and therefore more profitable to hunt in Asia, Australasia and Oceania). In these areas, if hunting 
columbids is for a source of protein, then there need to be sustainable agricultural development initiatives that increase existing protein production, or provide alternative protein sources. If hunting is to obtain cash from their trade then sustainable development initiatives that provide community members with an alternative source of income are needed.

Quantification of harvesting levels is difficult to determine. One indication is the level of trade in species. CITES monitors international trade in controlled columbid species. Five species are listed on CITES Appendices I - III (CITES, 2007); all were listed at the start of CITES in either 1975/1976. No illegal trade has been recorded for any species currently listed on CITES Appendices since 1989 (calculated from CITES, 2007), indicating that illegal international trade does not represent a significant threat to CITES-listed species.

CITES regulations do not regulate the international trade in non-CITES species, which is known to exist although is rarely quantified. Surveys of trade in nonCITES bird species in South-east Asia (which included an Appendix III species that was not widely recognized in the region) identified Indonesia to be the most active trader in its own wildlife in South-east Asia (Nash, 1993). Trade in 32 non-CITES wild columbids in Southeast Asia was recorded, with a significant export trade in fruit doves Ptilinopus spp. and imperial pigeons Ducula spp., particularly from West Papua.

National trade is harder to monitor. In Indonesia Shepherd et al. (2004) monitored the live bird trade in Medan, Sumatra, a major centre in the domestic and international trade of wildlife, between 1997 and 2001. They recorded 17 identified and five unidentified species of columbid for sale as meat, songbirds, pets, or for ceremonial/medicinal purposes. The traded species included both Near Threatened and globally threatened species. Not all hunted columbids make it to formal markets, and unknown quantities are sold by roadside or opportunistic traders or are for personal use/ consumption. Hunting of rare columbid species is legal in some countries (BirdLife International, 2005a) and records obtained opportunistically show that capture and informal trade of Globally Threatened species still takes place (BirdLife International, 2005b). Although numbers of birds captured for personal use and local domestic trade are completely unknown, given that hunting, mostly for subsistence food, is listed as a threat to $76 \%$ of threatened and $50 \%$ of Near Threatened columbid species it is likely to continue to represent a significant pressure on many columbid populations.

Introduced alien species Eighteen species are listed as threatened from introduced alien species (predators, competitors, and pathogens/parasites). Such species are currently only a threat to species that inhabit islands.
Introduced predators that have resulted in columbid declines are most commonly rats Rattus spp. and feral cats Felis catus, but include crab-eating macaques Macaca fascicularis, possums Trichosurus vulpecula, swamp harriers Circus approximans, and mongooses Herpestes auropunctatus (Clout et al., 1995; Gibbs et al., 2001; Powlesland et al., 2003). The destruction or degradation of columbid habitat from introduced/invasive species is also a problem. For example, feral goats and pigs have destroyed large patches of the natural forest habitat of the Marquesan imperial pigeon, an arboreal species restricted to the French Polynesian island of Nuku Hiva, and was the cause of the threat categorization of this species (Villard et al., 2003). To assess and address the influence of alien species on columbids requires the identification of their roles (competitors, predators, modifiers of habitat) and effects on columbid food supply, mortality levels and nesting success. The control of alien species with negative impacts on columbids, however, will depend on the species in question.

\section{Future research and priorities}

Good quality data are only available for $14 \%$ of threatened species. This is a great hindrance to halting and reversing population declines. To manage wild populations effectively and to identify and manage species that may require ex situ conservation efforts, research is needed to determine species' distributions and population sizes and identify species' resource requirements and reproductive output.

Most threatened columbids are tropical forest species but these are notoriously difficult to observe and study. For example, columbid calls are often superficially similar and identification of a species' full repertoire can be time consuming. Reliance on just the most common contact calls of species, however, will lead to lost potential from fieldwork and possible under-recording of species in studies of population sizes. Such problems can lead to information degradation in both data collection and analyses as species are sometimes lumped together, possibly because of ambiguous identification or because insufficient species-specific data are collected (Marsden, 1998). Effective and efficient methods to collect and analyse data need to be developed and shared amongst both researchers and managers.

Although such data are still required for most threatened species, urgent conservation attention needs to be focused on the Philippines and French Polynesia where a great proportion of columbid species are already threatened or Near Threatened, and where species are likely to become Near Threatened or threatened in the future. In addition, Indonesia should receive attention given the country's continued deforestation and the 
high number of columbid species that could become threatened should this trend continue. One particular genus of terrestrial doves, Gallicolumba, requires urgent research and conservation attention. Of the 20 species in this genus, three species are already extinct, 10 are threatened with extinction $(17 \%$ of the world's threatened species) and three are Near Threatened. Twelve (71\%) of these species occur in Indonesia, the Philippines or French Polynesia.

A few pigeon species have been the subjects of autecological research and successful conservation action; for example, captive breeding programmes have brought two species of pigeon back from the brink of extinction, the pink pigeon and Socorro dove (Butchart et al., 2006). In New Zealand there is considerable interest and commitment to conserving the country's only native species of pigeon, the Near Threatened New Zealand pigeon Hemiphaga novaeseelandiae, which has suffered rapid declines in recent years. Several projects are now working to highlight the plight of the species and secure its long-term future. Such timely awareness, and conservation commitment and resources, need to be generated and targeted towards the many threatened pigeon and dove species in the tropics.

\section{Acknowledgements}

I would like to thank Stuart Butchart (BirdLife International), Elizabeth Mutch, Noorainie (TRAFFIC), Sue Shutes (BirdLife International), David Orchard and two anonymous reviewers.

\section{References}

Baptista, L.F., Trail, P.W. \& Horblit, H.M. (1997) Family Columbidae (pigeons and doves). In Handbook of the Birds of the World, Vol. 4: Sandgrouse to Cuckoos (eds J. del Hoyo, A. Elliot \& J. Sargatal), pp. 60-243. Lynx Edicions, Barcelona, Spain.

Bennett, P.M. \& Owens, I.P.F. (1997) Variation in extinction risk among birds: chance or evolutionary predisposition? Proceedings of the Royal Society of London Series B-Biological Sciences, 264, 401-408.

BirdLife International (2005a) Species Factsheet: Gallicolumba xanthonura. Http://www.birdlife.org [accessed 26 October 2005].

BirdLife International (2005b) First Photos of Rare Dove. Http://www.birdlife.org/news/news/2005/02/ wetar_ground-dove.html [accessed 28 February 2005].

BirdLife International (2007) Bird Species Information Database. Http://www.birdlife.org/datazone/species/index.html [accessed 7 April 2007].

Butchart, S.H.M., Stattersfield, A.J. \& Collar, N.J. (2006) How many bird extinctions have we prevented? Oryx, 40, 266-278.

Chapman, C.A. \& Chapman, L.J. (1995) Survival without dispersers - seedling recruitment under parents. Conservation Biology, 9, 675-678.
CITES (2007) Trade Database. Http://www.cites.org/index.html [accessed 7 April 2007].

Clout, M.N., Karl, B.J., Pierce, R.J. \& Robertson, H.A. (1995)

Breeding and survival of New Zealand pigeons Hemiphaga novaeseelandiae. Ibis, 137, 264-271.

Corlett, R.T. (1998) Frugivory and seed dispersal by vertebrates in the Oriental (Indomalayan) region. Biological Reviews, $73,413-48$.

FAO (2005) State of the World's Forests 2005. Food and Agriculture Organization of the United Nations, Rome, Italy. FWI/GFW (2002) The State of the Forest: Indonesia. Forest Watch Indonesia, Bogor, Indonesia \& Global Forest Watch, Washington, DC, USA.

Gibbs, D., Barnes, E. \& Cox, J. (2001) Pigeons and Doves. Pica Press, Robertsbridge, UK.

Goodwin, D. (1983) Pigeons and Doves of the World, 3rd edition. Cornell University Press, New York, USA.

Hamann, A. \& Curio, E. (1999) Interactions among frugivores and fleshy fruit trees in a Philippine submontane rainforest. Conservation Biology, 13, 766-773.

Hughes, A.L. (2004) A statistical analysis of factors associated with historical extinction and current endangerment of nonpasserine birds. Wilson Bulletin, 116, 330-336.

IUCN (2006) 2006 IUCN Red List of Threatened Species. IUCN, Gland, Switzerland [http://www.redlist.org, accessed 15 June 2007].

Jati, A. (1998) Abundance and distribution of avifauna based on the forest fragmentation and habitat stratification in Langgaliru Nature Reserve, Sumba. MSc thesis, Bogor Agricultural Institute, Bogor, Indonesia.

Jones, M.J., Linsley, M.D. \& Marsden, S.J. (1995) Population sizes, status and habitat associations of the restricted-range species of Sumba, Indonesia. Bird Conservation International, 5, 21-52.

Kavanagh, R.P. \& Stanton, M.A. (2005) Vertebrate species assemblages and species sensitivity to logging in the forests of north-eastern New South Wales. Forest Ecology and Management, 209, 309-341.

Marsden, S.J. (1998) Changes in bird abundance following selective logging on Seram, Indonesia. Conservation Biology, 12, 605-611.

McConkey, K.R. \& Drake, D.R. (2002) Extinct pigeons and declining bat populations: are large seeds still being dispersed in the tropical Pacific? In Seed Dispersal and Frugivory: Ecology, Evolution and Conservation (eds D.J. Levey, W.R. Silva \& M. Galetti), pp. 381-395. CABI Publications, Wallingford, UK.

McConkey, K.R., Meehan, H.J. \& Drake, D.R. (2004) Seed dispersal by Pacific pigeons (Ducula pacifica) in Tonga, Western Polynesia. Emu, 104, 369-376.

Meehan, H.J., McConkey, K.R. \& Drake, D.R. (2005) Early fate of Myristica hypargyraea seeds dispersed by Ducula pacifica in Tonga, Western Polynesia. Austral Ecology, 30, 374-382.

Nash, S.V. (1993) Sold for a Song - The Trade in Southeast Asian Non-CITES Birds. TRAFFIC, Cambridge, UK.

Owens, I.P.F. \& Bennett, P.M. (2000) Ecological basis of extinction risk in birds: habitat loss versus human persecution and introduced predators. Proceedings of the National Academy of Sciences of the United States of America, 97, 12144-12148.

Peh, K.S.-H., de Jong, J., Sodhi, N.S., Lim, S.L.-H. \& Yap, C.A.-M. (2005) Lowland rainforest avifauna and human disturbance: persistence of primary forest birds in selectively logged forests 
and mixed-rural habitats of southern Peninsular Malaysia Biological Conservation, 123, 489-505.

Powlesland, R.G., Wills, D.E., August, A.C.L. \& Augus, C.K. (2003) Effects of a 1080 operation on kaka and kereru survival and nesting success, Whirinaki Forest Park. New Zealand Journal of Ecology, 27, 127-137.

Price, O.F., Woinarski, J.C.Z. \& Robinson, D. (1999) Very large area requirements for frugivorous birds in monsoon rainforests of the Northern Territory, Australia. Biological Conservation, 91, 169-180.

Shepherd, C.R., Sukumaran, J. \& Wich, S.A. (2004) Open Season: An Analysis of the Pet Trade in Medan, Sumatra 1997-2001. TRAFFIC, Cambridge, UK.

Stattersfield, A.J., Crosby, M.J., Long, A.J. \& Wege, D.C. (1998) Endemic Bird Areas of the World: Priorities for Biodiversity Conservation. ICBP, Cambridge, UK.

Stiles, F.G. (1985) On the role of birds in the dynamics of neotropical forests. In Conservation of Tropical Forest Birds (eds J.M. Diamond \& T.E. Lovejoy), pp. 49-212. ICBP, Cambridge, UK.

Thornton, I.W.B., Compton, S.G. \& Wilson, C.N. (1996) The role of animals in the colonisation of the Krakatau Islands by fig trees (Ficus species). Journal of Biogeography, 23, 577-592.

Villard, P., De Visscher, M.-N. \& Blanca, G. (2003) Population size, habitats and conservation of Marquesan imperial pigeon Ducula galeata. Bird Conservation International, 13, 189-197.

Walker, J.S. (2006) Resource use and rarity among frugivorous birds in tropical rain forest on Sulawesi. Biological Conservation, 130, 60-69.
Warburton, N.H. (1997) Structure and conservation of forest avifauna in isolated rainforest remnants in tropical Australia. In Tropical Forest Remnants (eds W.F. Laurance \& R.O. Bierregaard), pp. 190-206. University of Chicago Press, Chicago, USA.

Whittaker, R.J. \& Jones, S.H. (1994) The role of frugivorous bats and birds in the rebuilding of a tropical forest ecosystem, Krakatau, Indonesia. Journal of Biogeography, 21, 245-258.

Whittaker, R.J. \& Turner, B.D. (1994) Disperal, fruit utililization and seed predation of Dysoxylum gaudichaudianum in early successional rainforest, Krakatau, Indonesia. Journal of Tropical Ecology, 10, 167-181.

Wright, S.J. \& Duber, H.C. (2001) Poachers and forest fragmentation alter seed dispersal, seed survival, and seedling recruitment in the palm Attalea butyraceae, with implications for tropical tree diversity. Biotropica, 33, 583-595.

\section{Biographical sketch}

Jonathan Walker has studied frugivorous pigeon feeding ecology in the tropical forests of Indonesia for several years and has long championed the conservation of columbids (see http://www.columbidae.org.uk). His major research interests include extinction risk in birds, frugivory, and sustainable agriculture.

\section{Appendix}

Distribution of columbid genera and species following the taxonomy and geographic divisions adopted by BirdLife International (2007). Vagrants and introduced species are not included.

\begin{tabular}{|c|c|c|c|c|c|c|c|c|c|c|c|c|c|c|}
\hline \multirow[b]{2}{*}{ Genus } & \multicolumn{6}{|l|}{ Americas } & \multicolumn{4}{|c|}{$\begin{array}{l}\text { Europe, Africa, the Middle } \\
\text { East \& Central Asia }\end{array}$} & \multicolumn{3}{|c|}{$\begin{array}{l}\text { Asia, Australasia } \\
\text { \& Oceania }\end{array}$} & \multirow[b]{2}{*}{ Total $^{1}$} \\
\hline & Antarctica & $\begin{array}{l}\mathrm{S} \\
\text { America }\end{array}$ & $\begin{array}{l}\text { Andes } \\
\text { America }\end{array}$ & $\begin{array}{l}\mathrm{C} \\
\text { America }\end{array}$ & Caribbean & $\begin{array}{l}\mathrm{N} \\
\text { America }\end{array}$ & Africa & Europe & $\begin{array}{l}\text { Middle } \\
\text { East }\end{array}$ & $\begin{array}{l}\text { C } \\
\text { Asia }\end{array}$ & Asia & Australasia & Oceania & \\
\hline Columba & & 1 & 1 & 1 & 1 & 1 & 16 & 6 & 5 & 6 & 17 & 3 & 2 & 35 \\
\hline Streptopelia & & & & & 1 & 1 & 10 & 3 & 6 & 3 & 5 & & & 13 \\
\hline Stigmatopelia & & & & & & & 1 & 1 & 1 & 1 & 2 & & & 2 \\
\hline Treron & & & & & & & 5 & & 1 & & 18 & & & 23 \\
\hline Oena & & & & & & & 1 & & 1 & & & & & 1 \\
\hline Patagioenas $^{2}$ & & 8 & 13 & 9 & 8 & 4 & & & & & & & & 17 \\
\hline Leptotila & & 3 & 9 & 5 & 4 & 1 & & & & & & & & 11 \\
\hline Columbina & & 7 & 7 & 4 & 4 & 3 & & & & & & & & 9 \\
\hline Zenaida & $1^{3}$ & 2 & 5 & 4 & 4 & 4 & & & & & & & & 7 \\
\hline Geotrygon & & 4 & 7 & 9 & 6 & 2 & & & & & & & & 16 \\
\hline Claravis & & 2 & 2 & 2 & 1 & & & & & & & & & 3 \\
\hline Metriopelia & & 4 & 3 & & & & & & & & & & & 4 \\
\hline Uropelia & & 1 & 1 & & & & & & & & & & & 1 \\
\hline Starnoenas & & & & & 1 & & & & & & & & & 1 \\
\hline Ectopistes $^{4}$ & & & & & & 1 & & & & & & & & 1 \\
\hline Nesoenas & & & & & & & 2 & & & & & & & 2 \\
\hline Dysmoropelia ${ }^{4}$ & & & & & & & 1 & & & & & & & 1 \\
\hline Alectroenas & & & & & & & 5 & & & & & & & 5 \\
\hline Aplopelia & & & & & & & 1 & & & & & & & 1 \\
\hline Turtur & & & & & & & 5 & & & & & & & 5 \\
\hline
\end{tabular}


Appendix (Continued)

\begin{tabular}{|c|c|c|c|c|c|c|c|c|c|c|c|c|c|c|}
\hline \multirow[b]{2}{*}{ Genus } & \multicolumn{6}{|l|}{ Americas } & \multicolumn{4}{|c|}{$\begin{array}{l}\text { Europe, Africa, the Middle } \\
\text { East \& Central Asia }\end{array}$} & \multicolumn{3}{|c|}{$\begin{array}{l}\text { Asia, Australasia } \\
\text { \& Oceania }\end{array}$} & \multirow[b]{2}{*}{ Total $^{1}$} \\
\hline & Antarctica & $\begin{array}{l}\text { S } \\
\text { America }\end{array}$ & $\begin{array}{l}\text { Andes } \\
\text { America }\end{array}$ & $\begin{array}{l}\mathrm{C} \\
\text { America }\end{array}$ & Caribbean & $\begin{array}{l}\mathrm{N} \\
\text { America }\end{array}$ & Africa & Europe & $\begin{array}{l}\text { Middle } \\
\text { East }\end{array}$ & $\begin{array}{l}\text { C } \\
\text { Asia }\end{array}$ & Asia & Australasia & Oceania & \\
\hline Gallicolumba & & & & & & & & & & & 10 & 7 & 6 & 20 \\
\hline Ducula & & & & & & & & & & & 23 & 16 & 5 & 37 \\
\hline Ptilinopus & & & & & & & & & & & 30 & 19 & 15 & 50 \\
\hline Caloenas & & & & & & & & & & & 1 & 1 & 1 & 1 \\
\hline Geopelia & & & & & & & & & & & 4 & 3 & & 5 \\
\hline Macropygia & & & & & & & & & & & 8 & 3 & & 9 \\
\hline Reinwardtoena & & & & & & & & & & & 1 & 2 & & 3 \\
\hline Chalcophaps & & & & & & & & & & & 2 & 2 & & 2 \\
\hline Gymnophaps & & & & & & & & & & & 2 & 2 & & 3 \\
\hline Goura & & & & & & & & & & & 3 & 2 & & 3 \\
\hline Trugon & & & & & & & & & & & 1 & 1 & & 1 \\
\hline Otidiphaps & & & & & & & & & & & 1 & 1 & & 1 \\
\hline Henicophaps & & & & & & & & & & & 1 & 2 & & 2 \\
\hline Phapitreron & & & & & & & & & & & 4 & & & 4 \\
\hline Turacoena & & & & & & & & & & & 2 & & & 2 \\
\hline Cryptophaps & & & & & & & & & & & 1 & & & 1 \\
\hline Microgoura ${ }^{4}$ & & & & & & & & & & & & 1 & & 1 \\
\hline Phaps & & & & & & & & & & & & 3 & & 3 \\
\hline Ocyphaps & & & & & & & & & & & & 1 & & 1 \\
\hline Geophaps & & & & & & & & & & & & 3 & & 3 \\
\hline Petrophassa & & & & & & & & & & & & 2 & & 2 \\
\hline Leucosarcia & & & & & & & & & & & & 1 & & 1 \\
\hline Lopholaimus & & & & & & & & & & & & 1 & & 1 \\
\hline Drepanoptila & & & & & & & & & & & & 1 & & 1 \\
\hline Hemiphaga & & & & & & & & & & & & 1 & & 1 \\
\hline Didunculus & & & & & & & & & & & & & 1 & 1 \\
\hline Total genera & 1 & 9 & 9 & 7 & 9 & 8 & 10 & 3 & 4 & 3 & 20 & 23 & 6 & 44 \\
\hline Total species & 1 & 32 & 48 & 34 & 30 & 17 & 47 & 10 & 14 & 10 & 136 & 78 & 30 & 317 \\
\hline
\end{tabular}

${ }^{1}$ Represents the total number of species within each genus, not the row total, which is sometimes higher because species can occur in more than one region.

${ }^{2}$ Formed from splitting Columba in 2003

${ }^{3}$ Eared dove Zenaida auriculata occurs on South Georgia and the South Sandwich Islands

${ }^{4}$ Extinct genus 